\title{
萧
}

\section{Genesis 2 en 3 in 1 Timoteus 2: 'n motivering vir gedrag in die erediens, die gewone lewe of die huwelik?}

\author{
Douw G. Breed
}

Skool vir Bybelwetenskappe en Bybeltale

Potchefstroomkampus

Noordwes-Universiteit

POTCHEFSTROOM

E-pos: dbreed@telkomsa.net

\begin{abstract}
Genesis 2 and 3 in 1 Timothy 2: a rationale for conduct in public worship, ordinary life, or marriage?

In his exegesis of 1 Timothy 2:1-12, Breed (2006:247-261) shows that Paul does not give any indications in this text itself of whether the instructions in verses 8-12 were aimed at regulating conduct during public worship, in ordinary life or marriage. Paul supports the instructions he gives in 1 Timothy 2:11-12 in verses 13-15 by referring to Genesis 2 and 3. This article investigates whether there is any indication in Paul's rationale of the context in which these instructions should be read. The study focuses on Paul's reference to the order of creation ( $v$. 13), Eve's temptation (v. 14a), the state of transgression in which woman finds herself and her salvation by giving birth ( $v$. 14b-15). This study concludes that in his references to Genesis 2 and 3, Paul does not give any indications of whether this instructions in 1 Timothy 2:8-15 deals with instructions for public worship, ordinary life or marriage.
\end{abstract}

\section{Opsomming}

Genesis 2 en 3 in 1 Timoteus 2: 'n motivering vir gedrag in die erediens, die gewone lewe of die huwelik?

In sy eksegese van 1 Timoteus 2:1-12 toon Breed (2006:247261) aan dat Paulus geen aanduiding in hierdie teks self daarvan gee of hy in verse 8-12 opdragte gee vir gedrag in die erediens, die gewone lewe of die huwelik nie. Paulus motiveer die opdragte wat hy in 1 Timoteus 2:11-12 gee in verse 13-15 
deur na Genesis 2 en 3 te verwys. Daar word in hierdie artikel ondersoek ingestel of Paulus in hierdie motivering enige aanduiding bied van die konteks waarbinne die opdragte verstaan moet word. Daar word in die artikel opvolgend aandag gegee aan Paulus se verwysing na die skeppingsvolgorde (v. 13), die verleiding van Eva (v. 14a) en die staat van oortreding waarin die vrou gekom het en die vrou se redding deur geboorte te skenk (v. 14b-15). In hierdie artikel word bevind dat Paulus nie in sy verwysing na Genesis 2 en 3 enige aanduiding gee of hy in 1 Timoteus 2:8-12 hierdie voorskrifte gee vir bepaling vir die gedrag in die erediens, die gewone lewe of die huwelik nie.

\section{Inleiding}

Wanneer Paulus se voorskrifte in 1 Timoteus 2 bestudeer word, blyk dit dat daar nie sonder behoorlike begronding aanvaar kan word dat Paulus in dié gedeelte oor gedrag in die erediens handel nie. Breed (2006:247-261) toon aan in 'n bestudering van Paulus se voorskrifte vir gebed (v. 1-8), kleredrag (v. 9-10) en sy voorskrifte aangaande leer, onderrig en gesag uitoefen (v. 11-12) dat, anders as wat die meeste skrywers aanneem (vgl. byvoorbeeld Barnett, 1989:225; Cairns, 1995:151; Groenewald, 1977:34-39; Guthrie, 1978:69; Howard, 1983:39-40; Osiek \& Balch, 1997:121; Ridderbos, 1967:7986 ), dit ook moontlik is dat Paulus in dié gedeelte oor gedrag in die gewone lewe of die huwelik handel.

Die verhouding tussen mans en vroue word tans wêreldwyd intens bespreek. Omdat Paulus se voorskrifte aan mans en vroue in 1 Timoteus 2 lig kan werp op hierdie saak, is dit van groot belang dat duidelikheid verkry word oor die konteks waarbinne hierdie voorskrifte verstaan moet word.

Die voorskrifte wat Paulus in 1 Timoteus 2:11-12 gee, motiveer hy in verse 13-15. Hierdie motivering kan moontlik 'n aanduiding gee hoe die voorafgaande voorskrifte verstaan moet word en dus word die motivering in hierdie artikel bestudeer. Nadat 'n moontlike gedagtestruktuur van 1 Timoteus gegee is, word aandag gegee aan die skeppingsvolgorde wat Paulus in vers 13 ter sprake bring en die verleiding van Eva volgens vers 14 . Ten slotte word die staat van oortreding waarin die vrou gekom het (vgl. v. 14) bestudeer en die redding wat sy deur geboorte te skenk ontvang (vgl. v. 15). Aan die einde van die artikel word 'n aantal gevolgtrekkings gemaak. 


\section{2. 'n Moontlike gedagtestruktuur van 1 Timoteus}

Breed (2006:249-250) toon aan dat die volgende uiteensetting as 'n verantwoordbare gedagtestruktuur van 1 Timoteus kan dien:

1:1-2 Die aanhef

1:3-20 Die opdrag aan Timoteus

2:1-6:2a Betaamlike optrede van mense wat tot God se huisgesin behoort, teenoor die leer en gedrag wat die valse leraars voorgestaan het

6:2b-19 Finale opdragte

6:20-21 Briefslot

Die gedagte-eenheid waarbinne 1 Timoteus 2 voorkom, te wete 2:1$6: 2 a$, sou soos volg in kleiner gedagte-eenhede uiteengesit kon word:

2:1-15 Gedrag van gelowiges

3:1-13 Gedrag van ouderlinge en diakens

3:14-16 Die doel van die brief: die gedrag van God se huisgesin

4:1-14 Die leer en gedrag van die vals leraars

5:1-6:2a Gedrag van verskillende groepe binne die kerk

\section{Die skeppingsvolgorde}

Paulus beklemtoon in 2:13 dat Adam eerste gemaak is en Eva daarna. Die volgorde waarin God Adam en Eva geskape het, hou volgens $2: 13$ in dat vroue in onderdanigheid en met innerlike kalmte ${ }^{1}$ sal leer $(2: 11)$ en nie onderrig sal gee en so oor mans gesag uitoefen ${ }^{2}$ nie (2:12). Dit blyk dat Paulus uit die skeppingsvolgorde aflei dat God aan mans sekere gesag gegee het wat deur die vroue erken moet word.

1 Breed (2006:254-255) toon aan dat Paulus met $h \xi$ UC i a in 2:11 na innerlike kalmte verwys.

2 Mounce (2000:130) toon oortuigend aan dat die skrywer met die verbod om gesag uit te oefen, 'n beginsel stel. Met die verbod aan vroue om onderrig te gee, gee hy 'n spesifieke toepassing van die beginsel. Vergelyk ook Breed (2006:259). 
Dit is egter duidelik dat daar nie uit Paulus se verwysing na die skeppingsvolgorde afgelei kan word of hy in verse 11-12 na gesag van mans in die erediens, die gewone lewe of die huwelik verwys nie. Dit is moontlik dat Paulus in 2:11-12 die erediens in gedagte het en dat hy in 2:13 veronderstel dat mans, as gevolg van God se skeppingsvolgorde, 'n posisie van gesag in die erediens ontvang het wat vroue moet erken. Gelowige vroue sal hierdie gesag erken as hulle in die erediens met innerlike kalmte en in alle onderdanigheid leer wanneer mans daar onderrig gee. Indien hulle in die erediens oor mans gesag sou uitoefen, deur daar onderrig te gee, sou hulle die gesag wat God deur die skeppingsvolgorde aan die mans toegeken het, nie erken nie.

Dit is ook moontlik dat Paulus in 2:13 vir vroue beklemtoon dat hulle in die gewone lewe die gesag wat God deur die skeppingsvolgorde aan die man gegee het, moet erken. Wanneer hulle in die gewone lewe met innerlike kalmte en in alle onderdanigheid van mans leer en wanneer hulle nie oor mans gesag uitoefen deur voortdurend vir hulle voor te skryf nie ${ }^{3}$, erken hulle die gesag of posisie wat God aan mans toegeken het.

Paulus sou ook in 2:13 voorskrifte vir die huwelik kon motiveer. Hy wys volgens hierdie interpretasie daarop dat God, deur Adam eerste te skep en daarna Eva, aan die man sekere gesag in die huwelik gee. Indien in ag geneem word dat Paulus in Efesiërs 5:22 sê dat die man die hoof is van sy vrou, sou afgelei kon word dat hy in 1 Timoteus 2:12 hierdie hoofskap van mans in die huwelik veronderstel (vgl. Breed, 2005:255-256). God gee hiervolgens deur die skeppingsvolgorde aan die man spesifieke gesag, te wete dat hy sy vrou se hoof is. Hierdie hoofskap sal die vrou erken as sy met innerlike kalmte en in alle onderdanigheid van haar man leer en nie oor hom gesag probeer uitoefen deur aan hom voor te skryf nie.

\section{Adam wat nie verlei is nie en Eva wat wel verlei is}

In 2:14 motiveer Paulus verder die voorskrifte in 2:11-12, deur daarop te wys dat Adam nie verlei is nie, maar dat die vrou verlei is 4 en in oortreding gekom het. Die feit dat Paulus die woorde a p a t a w

3 Dit is moontlik dat Paulus met die woord didas kw na die betekenis voorskryf verwys (vgl. Breed, 2005:256-259).

$4 \quad$ Nie seksuele verleiding nie - vgl. Towner (1989:313-314) en Mounce (2000: 142). 
en exapat a w in 2:14 gebruik, gee 'n aanduiding dat hy na Genesis 3 verwys en spesifiek na Eva se antwoord toe God aan haar gevra het wat sy gedoen het: i0 of i" hpaths em me (vgl. die LXX, Gen. 3:13). Dit blyk dat Paulus deur te beklemtoon dat Adam nie verlei is nie, maar Eva wel, naas sy motivering in 2:13, verder wil aandui waarom dit belangrik is dat gelowige vroue die gesag wat God aan mans deur die skeppingsorde toegeken het (2:13), moet erken. Paulus stel dit in 2:14 voorop dat Adam nie verlei is nie. Daaruit mag nie afgelei word dat Paulus leer dat Adam minder skuld in die ongehoorsaamheid aan God gehad het nie. Uit die Skrifgedeelte waaruit hy aanhaal, is dit immers duidelik dat God wel vir Adam verantwoordelik gehou het vir die oortreding in die tuin van Eden. Paulus self dui ook uitdruklik in Romeine 5 Adam se skuld in die sondeval aan. Dit gaan dus nie in 2:14 daaroor wie van Adam en Eva die meeste skuldig is, of selfs oor die vraag of Adam sou gesondig het as Eva nie gesondig het nie. Paulus wil ook nie in 2:14 enige ontologiese eienskappe van 'n vrou of man bekend maak nie, byvoorbeeld dat die vrou meer verleibaar is as die man nie. Hy handel oor die gesag wat God deur die skeppingsvolgorde aan die man toegeken het - gesag waaraan Eva erkenning moes gee. Deur eers te sê dat dit nie Adam was wat verlei is nie en dan te sê dat dit wel Eva is wat verlei is, wys hy op die feit dat Eva, toe sy die leiding geneem het, nie haar man se gesag erken het nie. Sy het nie die onderdanigheid wat in 2:11 ter sprake is, geopenbaar nie. Inteendeel, sy het met die leiding wat sy geneem het, oor haar man gesag uitgeoefen. Sy het dus gedoen wat Paulus in 2:12 gelowige vroue verbied om te doen.

Dit is uit die voorgaande duidelik dat dit moontlik is dat Paulus in 2:14 gedrag in die erediens, die gewone lewe of die huwelik motiveer. Paulus sou in 2:14 kon stel dat vroue nie in die erediens dieselfde fout moet maak as Eva en die gesag wat God deur sy skeppingsvolgorde aan die man gegee het, moet misken nie. Dit sou hulle doen as hulle nie in die erediens met innerlike kalmte en in alle onderdanigheid leer nie, of as hulle daar oor die man gesag wil uitoefen, deur daar onderrig te gee.

Paulus sou ook in 2:14 vroue kon motiveer om nie soos Eva die gesag wat deur die skeppingsvolgorde aan die man gegee is, in die gewone lewe te misken nie. Dit sou hulle doen as hulle in die gewone lewe nie met innerlike kalmte en in alle onderdanigheid van mans leer nie, of as hulle oor mans gesag uitoefen, deur voortdurend vir mans voor te skryf. 
Paulus sou ook in 2:14 kon beklemtoon hoe belangrik dit is dat vroue in die huwelik die hoofskap van hulle mans moet erken. As hulle nie met innerlike kalmte en in alle onderdanigheid van hulle mans leer nie, en as hulle oor hulle mans gesag uitoefen deur vir hulle voor te skryf, erken hulle daarmee, net soos Eva, nie die hoofskap wat God aan hulle mans deur die skeppingsvolgorde gegee het nie.

\section{Die vrou wat in oortreding gekom het en die redding deur geboorte te skenk}

Paulus sê in 2:14 dat Eva, nadat sy verlei is, in oortreding gekom het (ej parabasei gegonen). Die perfektum gegonen dui die voortdurende gevolg van Eva se daad aan. Eva het in 'n staat van oortreding gekom. Dit blyk dat Paulus op hierdie gedagte voortbou, wanneer hy in 2:15 die redding van die vrou ter sprake bring. Dit wil voorkom of Paulus aanvaar dat die staat van oortreding waarin Eva gekom het, ook die staat is waarin alle vroue verkeer. Nadat hy in 2:15 gesê het dat sy (derde persoon enkelvoud wat duidelik na Eva verwys) deur geboorte te skenk gered sal word, sê hy dat hierdie redding sal plaasvind as hulle (meervoud wat na alle vroue verwys ${ }^{5}$ ) vasstaan.

Die feit dat Paulus vers 15 met die koppelwoord dì inlei, en dat hy in 2:14 gesê het dat Eva in 'n staat van oortreding gekom het, gee 'n aanduiding wat Paulus met die woord swahs et a i bedoel. Dit blyk dat hy $\mathrm{s}$ why s et a i nie in die semantiese veld psigologiese prosesse en toestande (vgl. Louw \& Nida, 1988:269) gebruik nie, maar in die semantiese veld gevaar, risiko, veilig, red vir die betekenis om te veroorsaak dat iemand goddelike redding ervaar (vgl. Louw \& Nida, 1988:242). Paulus sê dus alhoewel Eva en alle vroue in 'n staat van oortreding gekom het, hierdie toestand nie onveranderd hoef te bly nie. Goddelike redding is vir vroue moontlik.

Met die woorde dia; th" teknogonia" dui Paulus hoe redding ontvang kan word. Eksegete verskil grootliks met mekaar oor wat

5 Let daarop dat Paulus in 2:15 van die enkelvoud $\mathrm{s}$ wqh s et a i na die meervoud mei nws in oorgaan. Die staat waarin Eva gekom het, het ook die staat van alle vroue geword. Mounce (2000:143-147) toon aan dat die meervoud mei nws in nie op die kinders wat gebore is, wys nie, maar op alle vroue. 
die skrywer met hierdie woorde bedoel. 6 Die vraag is hoe Paulus kan sê dat redding deur geboorte te skenk gevind kan word, terwyl hy duidelik in sy ander briewe (vgl. byvoorbeeld Rom. 3:29) en ook in 1 Timoteus (vgl. 1:12-17) leer dat redding alleen deur die verlossingswerk van Christus verkry kan word. As antwoord op hierdie vraag poog Huizenga (1982:17-26) om aan te dui, dat die geboorte skenk wat in 2:15 ter sprake is, na die geboorte van Christus verwys. In die lig daarvan dat Paulus reeds in 2:13-14 na Genesis 2 en 3 verwys het, en in die lig van die belofte wat Eva volgens Genesis 2:15 ontvang, is hierdie interpretasie baie aantreklik. Mounce (2000:145) wys egter daarop dat die woord t eknogonia" die klem laat val op die daad van geboorte skenk en nie op die kind wat gebore word nie.

Dit val op dat Paulus in 4:16 ook, soos in 2:15, redding (vgl. 5 w) met goeie werke verbind. Hy sê dat Timoteus homself en andere sal red deur sekere dinge te doen (poiwh). Dit lyk onmoontlik dat Paulus, terwyl hy in 1:12-17 uitdruklik die verlossing deur genade leer, homself in 2:15 en 4:16 sou weerspreek deur verlossing deur goeie werke te leer. Dit is beter om te aanvaar dat Paulus in hierdie verse oor die noodsaaklikheid van goeie werke vir iemand wat die verlossing in Christus ontvang het, handel. Wanneer 2:15 en 4:16 só verstaan word, kom dit ooreen met ander plekke in die Skrif, te wete Hebreërs 2:1-4; 3:7-19; 6:12; 10:26-31; Jakobus 2:14-26; 1 Johannes 2:3-6 en 1 Petrus 1:5-11 (Schreiner, 1995:152-153). Paulus sê dus in 2:15 dat die vrou, wat deur verleiding van Eva in 'n staat van oortreding gekom het, deur geboorte te skenk, sal toon dat sy redding gevind het.

Dit is belangrik om te bepaal waarom Paulus sê dat juis deur geboorte te skenk 'n aanduiding sal wees dat die vrou redding gevind het. Verskeie skrywers (Kelly, 1972:70; Kroeger \& Kroeger, 1992:171-177; Mounce, 2000:146 en Schreiner, 1995:150) wys op die feit dat die vals leraars die huwelik as minderwaardig beskou het (vgl. 4:1-3), en dat daar aangeneem kan word dat die daad van geboorte skenk daarom ook geminag is. Paulus sê dus dat die gelowige vroue van Efese moet openbaar dat hulle 'n ander leer as die vals leraars aanhang, deur dit nie te minag om geboorte te skenk nie. Wanneer 'n vrou dit sou minag om geboorte te skenk,

6 Vgl. Holmes (2000:245-248) en Jebb (1969-1970:221-222) vir 'n uiteensetting van die verskillende wyses waarop die woorde dia; th" teknogonia" verstaan kan word. 
sou sy daarmee haar verlossing bevraagteken. Aan die ander kant, wanneer ' $n$ vrou dit beskou as 'n voorreg wat sy van God ontvang het om geboorte te skenk, toon sy daarmee dat sy die suiwer leer aanvaar en daarom gered is. Daar word egter nie in 2:15 geleer dat 'n vrou se standpunt oor die daad van geboorte skenk per se openbaar dat sy gered is nie. Vroue 7 moet volgens hierdie vers met ingetoënheid ook volhard in geloof, liefde en heiligmaking.

Wanneer gelet word op wat Paulus vanaf 2:11-14 van vroue beklemtoon, is dit duidelik dat hy met sy verwysing na geboorte skenk nie net die vals leer oor geboorte skenk bestry nie. In 2:11-14 beklemtoon Paulus uitdruklik dat vroue nie die godgegewe rol van mans mag inneem nie (vgl. Breed, 2006:254-259). In 2:15 beklemtoon hy die rol wat vroue van God - in onderskeiding van mans - ontvang. Dit blyk dus dat Paulus vereis dat die vroue van Efese enersyds nie die godgegewe rol van mans moet inneem nie (vgl. 2:11-12), en dat hulle andersyds moet toon dat hulle hulle verlossing gevind het deur hulle standpunt oor 'n baie spesifieke rol wat God aan die vrou gegee het.

Uit die voorafgaande kan afgelei word dat Paulus nie deur sy verwysing na geboorte skenk as die wyse waarop vroue bevestig dat hulle redding gevind het, 'n aanduiding gee van die konteks waarbinne die voorskrifte in 2:8-15 verstaan moet word nie. Indien Paulus in 2:11-12 vroue verbied om die man se godgegewe rol, naamlik om in die erediens te leer, in te neem, wys hy waarskynlik in 2:15 vir vroue op die godgegewe rol wat hulle wel ontvang het, te wete om geboorte te skenk. As hulle in geloof, liefde en heiligmaking met ingetoënheid volhard, sou hulle standpunt oor hierdie godgegewe rol aandui of hulle redding gevind het.

Indien Paulus in 2:11-12 vroue verbied om in die gewone lewe die man se gesag te misken, sou hy in 2:15 aandui watter godgegewe rol sy wel ontvang het, te wete om geboorte te skenk.

As Paulus in 2:11-12 van vroue vra om nie die man se hoofskap in die huwelik te misken nie, kan afgelei word dat hy in 2:15 vir hulle beklemtoon dat God aan hulle, in onderskeiding van die man, 'n rol gegee het, naamlik om geboorte te skenk. As hulle hierdie godgegewe rol hoog ag en met ingetoënheid volhard in geloof, liefde

$7 \quad$ Mounce (2000:143 en 147) toon oortuigend aan dat die meervoud mei nws in in 2:15 die analogie tussen die vroue van Efese en Eva uitlig. 
en heiligmaking, sou hulle daarmee toon dat hulle redding gevind het.

\section{Gevolgtrekkings}

Paulus gee nie deur sy verwysing na Genesis 2-3 enige aanduiding binne watter konteks die voorskrifte in 1 Timoteus 2:8-15 verstaan moet word nie. Die motivering in 1 Timoteus $2: 13-15$ sou kon dien as motivering vir gedrag in die erediens, die gewone lewe of die huwelik.

As Paulus (2:11-12) voorskrifte vir gedrag in die erediens gee, motiveer hy die voorskrifte, deur daarop te wys dat God aan mans sekere gesag gegee het deur Adam eerste te maak en daarna Eva. Hierdie gesag sal vroue erken as hulle hulle met innerlike kalmte en in alle onderdanigheid in die erediens laat leer, en as hulle nie in die erediens oor mans gesag uitoefen deur daar aan mans onderrig te gee nie. Hy hou in 2:14 Eva, wat met die sondeval die leiding geneem het en in die versoeking gekom het, as voorbeeld voor van iemand wat nie die godgegewe rol van die man erken het nie. Die vroue van Efese moet nie in die erediens dieselfde fout as Eva maak nie. Volgens 2:15 kan vroue, deur hulle standpunt oor die skenk van geboorte, toon dat hulle nie meer in die staat van oortreding verkeer waarin hulle saam met Eva beland het nie, maar dat hulle redding gevind het. As hulle met ingetoënheid volhard in geloof, liefde en heiligmaking, sal dit werklik duidelik wees dat hulle redding gevind het.

Indien Paulus (2:11-12) oor die gedrag van vroue in die gewone lewe handel, beklemtoon hy in 2:13-14 dat God aan die man sekere gesag gegee het deur Adam eerste te maak en daarna Eva. As vroue hulle deur mans laat leer en nie oor mans gesag uitoefen deur voortdurend vir mans voor te skryf nie, erken hulle hierdie gesag wat God aan mans gegee het. Paulus wys in 2:14 daarop dat Eva nie die gesag wat God aan Adam gegee het, erken het nie. As vroue nie op die voorskrifte in 2:11-12 ag gee nie, is hulle, net soos Eva, ongehoorsaam. Hoewel vroue volgens 2:11-12 nie die rol wat aan mans gegee is, mag inneem nie, het sy, in onderskeiding van die man, 'n besondere rol ontvang, te wete om geboorte te skenk. As sy hierdie rol hoog ag en met ingetoënheid volhard in geloof, liefde en heiligmaking, sal sy daardeur openbaar dat sy redding gevind het.

As aanvaar word dat Paulus in 2:11-12 aan Timoteus voorskrifte gee aangaande vroue se gedrag in die huwelik, wys hy in 2:13 eerstens daarop dat Adam eerste gemaak is en daarna Eva. Die 
volgorde waarin God die man en vrou geskape het, gee aan die man sekere gesag in die huwelik, te wete dat hy sy vrou se hoof is. Hierdie hoofskap sal die vrou erken as sy met innerlike kalmte en in alle onderdanigheid van haar man leer en nie oor hom gesag probeer uitoefen deur aan hom voor te skryf nie. Tweedens motiveer Paulus sy voorskrifte deur in vers 14 daarop te wys dat Adam nie verlei is nie, maar dat die vrou verlei is en in oortreding gekom het. Daarmee beklemtoon hy hoe belangrik dit is dat vroue in die huwelik die hoofskap van hulle mans moet erken. As hulle nie met innerlike kalmte en in alle onderdanigheid van hulle mans leer nie, en as hulle oor hulle mans gesag uitoefen deur vir hulle voor te skryf, maak hulle dieselfde fout as Eva met die sondeval - hulle erken nie die hoofskap wat God aan hulle mans deur die skeppingsvolgorde gegee het nie.

Terwyl Paulus in 2:11-12 die godgegewe rol van die man in die huwelik beklemtoon, beklemtoon hy in 2:15 'n spesifieke godgegewe rol van die vrou in die huwelik, naamlik om geboorte te skenk. Die vrou moet, anders as die vals leraars in Efese, hierdie godgegewe rol hoog ag. As sy dit doen en met ingetoënheid volhard in geloof, liefde en heiligmaking, toon sy daarmee dat sy redding gevind het.

\section{Geraadpleegde bronne}

BARNETT, P.W. 1989. Wives and woman's ministry (1 Timothy 2:11-15). The Evangelical Quarterly, 61(1):225-238.

BREED, D.G. 2005. 1 Timoteus 2:8-15: voorskrifte vir gedrag in die erediens, die gewone lewe of die huwelik? In die Skriflig, 40(2):247-263.

CAIRNS, H.D. 1995. 1 Timothy 2:8-3:1: woman's ordination in the light of the Christian self-definition of woman in Ephesus. Pretoria: Unisa. (Master of arts - Biblical studies.)

GROENEWALD, E.P. 1977. Die Pastorale Briewe. Kaapstad: NG KerkUitgewers.

GUTHRIE, D. 1978. The Pastoral Epistles. Grand Rapids: Eerdmans. (Tyndale New Testament Commentaries.)

HOLMES, J.M. 2000. Text in a whirlwind: a critique of four exegetical devices as 1 Timothy 2:9-15. Sheffield: Sheffield Academic Press.

HOWARD, J.K. 1983. Neither male nor female: an examination of the status of woman in the New Testament. Evangelical Quarterly, 55:31-42.

HUIZENGA, H. 1982. Woman, salvation and the birth of Christ: a reexamination of 1 Timothy 2:15. Studia Biblica et Theoligica, 12:17-26.

JEBB, S. 1969-1970. Short comment: a sugested interpretation of 1 Ti. 2:15. The Expository Times, 81:221-222.

KELLY, J.N.D. 1972. A commentary on the Pastoral Epistles: I and II Timothy, Titus. London: Black.

KROEGER, R.C. \& KROEGER, C.C. 1992. I suffer not a woman: rethinking 1 Timothy 2:11-15 in the light of ancient evidence. Michigan: Baker Book House. 
LOUW, J.P. \& NIDA, E.A. 1988. Greek-English lexikon of the New Testament based on semantic domains. Vol. 1. New York: United Bible Societies.

MOUNCE, W.D. 2000. Pastoral Epistles. Nashville: Nelson. (Word Biblical Commentary, vol. 46.)

OSIEK, C. \& BALCH, L.B. 1997. Families in the New Testament world: households and house churches. Kentucky: Westminster John Knox.

RIDDERBOS, D. 1967. De Pastorale Brieven. Kampen: N.V. Uitgeversmaatschappij. (Commentaar op het Nieuwe Testament.)

SCHREINER, T.R. 1995. An interpretation of 1 Timothy 2:9-15: a dialogue with scholarship. (In Köstenberger, A.J., Schreiner, T.R. \& Baldwin, H.S., eds. Woman in the church: a fresh analysis of 1 Timothy 2:9-15. Michigan: Baker Books. p. 105-154.)

TOWNER, P.H. 1989. The goal of our instruction: the structure of the theology and ethics in the Pastoral Epistles. Sheffield: Sheffield Academic Press.

\section{Kernbegrippe:}

1 Timoteus 2:13-15

huwelik

openbare erediens

vroue

\section{Key concepts:}

1 Timothy 2:13-15

marriage

public worship

woman 
